\title{
Intradural Extramedullary Ependymoma with Spinal Root Attachment: A Case Report
}

\author{
Seung Man $\mathrm{Ha}^{1}$, Dong Ah Shin ${ }^{2}$

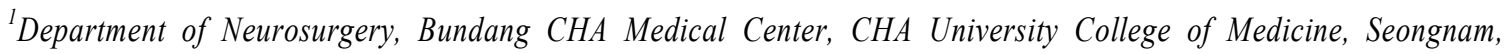 \\ ${ }^{2}$ Department of Neurosurgery, Spine and Spinal Cord Institute, Yonsei University College of Medicine, Seoul, Korea
}

A 36-year-old female patient presented with shoulder pain experienced over a period of one year and progressive weakness in both legs for one month. A magnetic resonance imaging scan revealed an intradural extramedullary (IDEM) fusiform mass about $9.8 \mathrm{~cm}$ in length, heterogeneously enhanced at the level of C6-T4 with spinal cord compression. At the time of surgery, the surgeon found an encapsulated IDEM tumor with spinal root attachment. The tumor was completely resected and the histologic diagnosis revealed ependymoma. The patient showed a favorable outcome with no recurrence at the 6-month follow-up. This paper reports a rare case of intradural extramedullary ependymoma with spinal root attachment.

Key Words: Ependymoma $\cdot$ Spinal tumor $\cdot$ Intradural extramedullary tumor $\cdot$ Surgery

\section{INTRODUCTION}

Ependymoma is an uncommon group of glial tumors arising in the central nervous system. Spinal cord ependymoma comprises less than $2 \%$ of all central nervous system neoplasms, $15 \%$ of spinal cord tumors, and up to $60 \%$ of spinal cord gliomas $^{20)}$. It is an intramedullary lesion and there have been reports of only 17 cases of ependymomas arising in IDEM

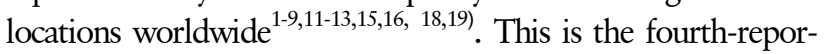
ted case of primary IDEM ependymoma in South Korea ${ }^{10,14,17)}$. However, it is the first cervico-thoracic-involved case of IDEM ependymoma with spinal root attachment.

\section{CASE REPORT}

A 36-year-old woman visited the hospital with complaints of progressive paraplegia, occurring for one month, and left shoulder pain of a year's duration. She had no past medical or surgical history. On the initial neurologic examination, the patient showed lower limb weakness (Grade III/III) in both

- Received: April 15, 2012 - Revised: September 23, 2012

- Accepted: September 25, 2012

Corresponding Author: Dong Ah Shin, MD

Department of Neurosurgery, Yonsei University College of Medicine, 50

Yonsei-ro, Seodaemun-gu, Seoul 120-752, Korea

Tel: +82-2-2228-2150, Fax: +82-2-393-9979

Email: cistern@yuhs.ac/shindongah@me.com limbs, hypoesthesia below T5, and bladder disturbance. Magnetic resonance imaging of the whole spine revealed an IDEM heterogeneously enhanced fusiform mass, about $9.8 \mathrm{~cm}$ in length, causing compression of the cord from the level of C6 upper body to T4 mid body (Fig. 1). Complete imaging of the rest of the neuroaxis revealed an arachnoid cyst in the right middle cranial fossa. The patient underwent surgical resection (Fig. 2). Surgeons performed a posterior C6 through T4 laminectomy, which allowed intradural exploration and removal of the IDEM mass, and a midline durotomy. The tumor was grossly yellowish in color and markedly distorted the spinal cord to the right. A stalk attached the tumor to the C7 spinal nerve root. The tumor was removed in a gross total fashion using standard microsurgical techniques. The patient tolerated the procedure well. Histolo- gical examination
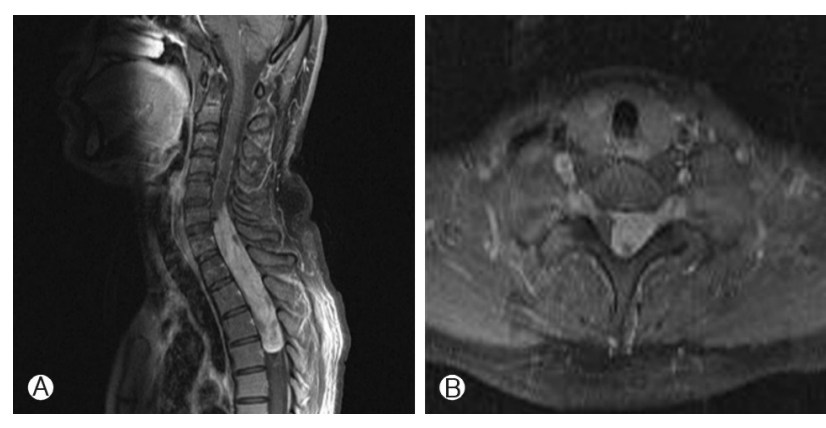

Fig. 1. Pre-operative $\mathrm{Tl}$-weighted, post contrast sagittal (A) and axial (B) magnetic resonance images demonstrating an enhanced mass from the level of C6 upper body to T4 mid body. 


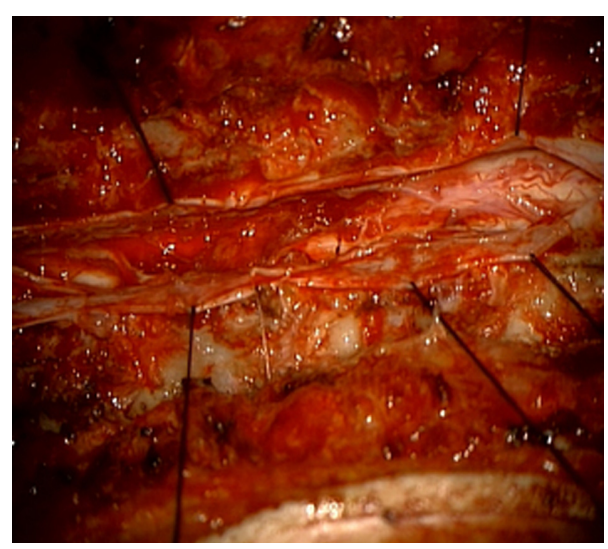

Fig. 2. Intra-operative photograph shows a reddish, extramedullary encapsulated tumor after opening of the dura mater.

revealed a WHO Grade II ependymoma with a proliferation index of $<1 \%$ measured by Ki-67 (Fig. 3). The patient's neurological status significantly improved after the surgery. Postoperative magnetic resonance imaging showed no definite residual enhancing mass. No adjuvant radiotherapy was offered to the patient. There was no recurrence on MRI at the 6-month follow up (Fig. 4).

\section{DISCUSSION}

Spinal cord ependymoma is an intradural intramedullary lesion most frequently located at the conus medullaris or filum terminale. Only rare reports exist of spinal cord ependymomas in IDEM locations; only 17 cases of spinal cord ependymomas in IDEM locations exist in the relevant literature ${ }^{-9,11-13,15,16,18,19)}$.

The overall prevalence of the majority of spinal ependymomas among males and females is equal but this neoplasm is more common in women; there were only 4 reported cases of male patients ${ }^{1,3,8,11}$. Although Duffau et al. ${ }^{5)}$ has postulated the insufficiency of hormonal theory, there are no reports of hormonal assessment. There is no predominant age group for patients with this lesion. Typical clinical features include a slowly progressive mye- lopathy with weakness and pain according to tumor location. A thoracic location is a common presentation. Compared with almost all other IDEM ependymoma patients in the literature who presented with myelopathy and axial pain, the patient in the current case showed a unilateral, radicular symptom (shoulder pain) in addition to myelopathy, probably caused by root compression from the root attachment. In most previous reports, MRI showed typically well delineated IDEM tumors that were homogeneously enhanced after gadolinium administration. Doctors often diagnosed as schwannomas or meningiomas due to similarities in

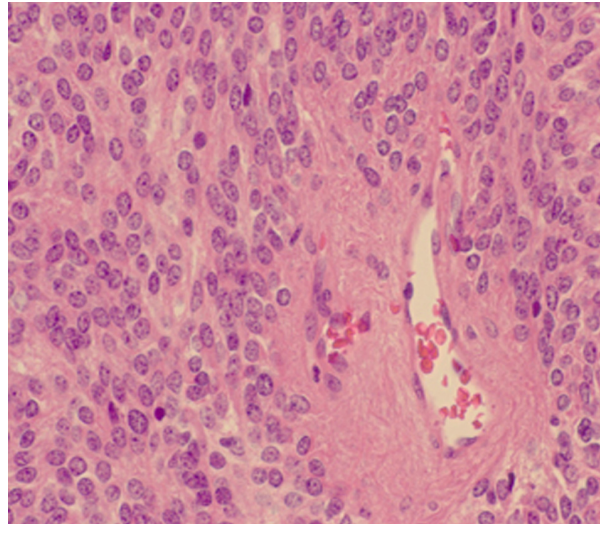

Fig. 3. Histologic examination reveals an ependymoma grade II. Tumor cells had round-to-oval nuclei. Eosinophilic cytoplasm and perivascular pseudorosette were evident.

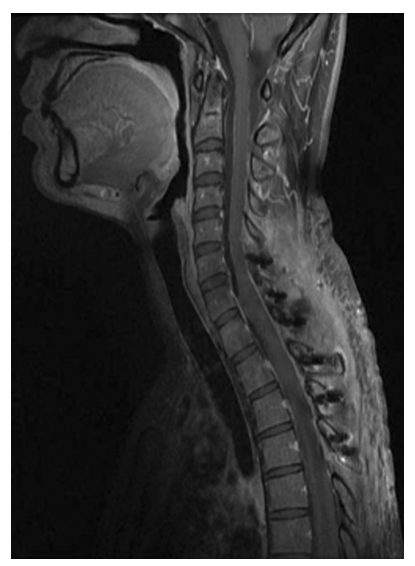

Fig. 4. Six months later, a postoperative Tl-weighted sagittal magnetic resonance image with gadolinium enhancement shows no recurrence of the gross totalresected tumor.

MRI findings and in clinical courses. Distinct from the other cases, the current case showed heterogenous enhancement, but intraoperative findings and pathologic findings were undistinguished $^{16}$. More case reports are needed to clarify the pathogenesis and clinical manifestations of this type of tumor.

In most previous reports, the lesions were encapsulated with only microvascular attachments to the central nervous system. This feature enabled complete resection. In two cases, there were thin stalks that connected the tumor to the spinal cord. In the case presented here, and in one reported by Bonfield et al. ${ }^{2)}$ there were spinal nerve root attachments in the intraoperative findings. In the current case, the tumor was removed safely during surgery with an ultrasonic aspirator because of the loose attachment. It appears that this case is the second reported IDEM ependymoma involving a spinal nerve root $^{2}$. Distinct from the current case, Bonfield et al. ${ }^{2)}$ decided on the resection of nerve root because of the dense attachment. It is probable that the separated ectopic ependymal tissue during neural tube closure was the origin of the tumor on the nerve root $^{11}$. Since prognosis is directly related to the extent of surgi- 
cal resection, complete resection of the tumor is the optimal therapy for IDEM ependymoma. In this case, despite the nerve attachment, no residual tumor appeared in surgical findings or on postoperative magnetic resonance imaging; therefore, no adjuvant radiotherapy was warranted. If there are tumor remnants or malignant cases, adjuvant radiotherapy should be considered. There were no signs of local recurrence or distant dissemination on MRI at the 6-month follow-up and the patient had no neurologic deficits. However, since anaplastic transformation $^{15)}$ and recurrence ${ }^{1)}$ have been reported in previous cases, regular follow-up evaluations are required.

\section{CONCLUSION}

This paper reports a rare case of intradural extramedullary ependymoma with spinal root attachment, which was successfully treated with gross total resection. Ependymoma should be included in the differential diagnosis of intradural extramedullary spinal cord tumors.

\section{Acknowledgement}

This study was supported by a grant from the Korea Healthcare Technology R\&D Project, Ministry for Health \& Welfare Affairs, Republic of Korea (A111016)

\section{REFERENCES}

1. Benzagmout M, Boujraf S, Oulali N, Chbani L, Amarti A, Chakour $\mathrm{K}$, et al: Intradural extramedullary ependymoma: is there constantly a hormonal relationship? Surg Neurol 70:536-538, 2008

2. Bonfield CM, Amin D, Hamilton RL, Gerszten PC: Extramedullary ependymoma near the conus medullaris with lumbar nerve root attachment: Case report. Neurosurgery 68:E831-834, 2011

3. Cerase A, Venturi C, Oliveri G, De Falco D, Miracco C: Intradural extramedullary spinal anaplastic ependymoma. Case illustration. J Neurosurg Spine 5:476, 2006

4. Cheng $\mathrm{CH}$, Lee TC, Huang HY, Lui CC: Extramedullary thoracic myxopapillary ependymoma-a case report of a rare tumour. Ann Acad Med Singapore 25:869-872, 1996
5. Duffau H, Gazzaz M, Kujas M, Fohanno D: Primary intradural extramedullary ependymoma: Case report and review of the literature. Spine (Phila Pa 1976) 25:1993-1995, 2000

6. Gonzalez Feria L, Fernandez Martin F, Ginoves Sierra M, Galera Davidson H: Giant dorsal extramedullary ependymoma. Arch Neurobiol (Madr) 34:325-332, 1971

7. Graca J, Gultasli N, D'Haene N, Brotchi J, Salmon I, Baleriaux D: Cystic extramedullary ependymoma. AJNR Am J Neuroradiol 27:818-821, 2006

8. Iunes EA, Stavale JN, de Cassia Caldas Pessoa R, Ansai R, Onishi FJ, de Paiva Neto MA, et al: Multifocal intradural extramedullary ependymoma. Case report. J Neurosurg Spine 14:65-70, 2011

9. Katoh S, Ikata T, Inoue A, Takahashi M: Intradural extramedullary ependymoma. A case report. Spine (Phila Pa 1976) 20: 2036-2038, 1995

10. Kim SY, Kim SW: Primary intradural extramedullary myxopapillary ependymoma. J Korean Neurosurg Soc 39:382-384, 2006

11. Kinsman MJ, Callahan JD, Hattab EM, Cohen-Gadol AA: Extramedullary spinal ependymoma: a diagnostic challenge and review of the literature. Clin Neurol Neurosurg 113:661-664, 2011

12. Oliver B, de Castro A, Sarmiento MA, Arguello C, Blazquez MG: Dorsal extramedullary ependymoma (author's transl). Arch Neurobiol (Madr) 44:215-224, 1981

13. Payer M, Yonekawa Y, Imhof HG: Solitary thoracic intradural extramedullary ependymoma. J Clin Neurosci 6:344-345, 1999

14. Rah JH, Ahn JI, Soon KM, Jung SH: Intradural extramedullary myxopapillary ependymoma in filum terminale - a case report -. J of Korean Orthop Assoc 28:1474-1478, 1993

15. Robles SG, Saldana C, Boto GR, Martinez A, Zamarron AP, Jorquera $\mathrm{M}$, et al: Intradural extramedullary spinal ependymoma: A benign pathology? Spine (Phila Pa 1976) 30:E251-254, 2005

16. Schuurmans M, Vanneste JA, Verstegen MJ, van Furth WR: Spinal extramedullary anaplastic ependymoma with spinal and intracranial metastases. J Neurooncol 79:57-59, 2006

17. Son DW, Song GS, Han IH, Choi BK: Primary extramedullary ependymoma of the cervical spine: Case report and review of the literature. J Korean Neurosurg Soc 50:57-59, 2011

18. Vural M, Arslantas A, Ciftci E, Artan S, Adapinar B: Multiple intradural-extramedullary ependymomas: proven dissemination by genetic analysis. J Neurosurg Spine 12:467-473, 2010

19. Wagle WA, Jaufman B, Mincy JE: Intradural extramedullary ependymoma: mr-pathologic correlation. J Comput Assist Tomogr 12:705-707, 1988

20. Yoo NH, Han SR, Yoon SW, Yee GT, Choi CY, Sohn MJ, et al: Spinal intramedullary ependymoma: - myxopapillary ependymoma vs. ependymoma -. Korean J Spine 2(3):199-203, 2005 